

CrossMark \&lick for updates

Cite this: Dalton Trans., 2016, 45 12167

Received 13th May 2016,

Accepted 27th June 2016

DOI: 10.1039/c6dt01897a

www.rsc.org/dalton

\section{Antimony oxofluorides - a synthesis concept that yields phase pure samples and single crystals $\uparrow$}

\begin{abstract}
Sk Imran Ali and Mats Johnsson*
The single crystals of the new isostructural compounds $\mathrm{Sb}_{3} \mathrm{O}_{4} \mathrm{~F}$ and $\mathrm{Y}_{0.5} \mathrm{Sb}_{2.5} \mathrm{O}_{4} \mathrm{~F}$ and the two previously known compounds $\mathrm{M}$-SbOF and $\alpha-\mathrm{Sb}_{3} \mathrm{O}_{2} \mathrm{~F}_{5}$ were successfully grown by a hydrothermal technique at $230{ }^{\circ} \mathrm{C}$. The new compound $\mathrm{Sb}_{3} \mathrm{O}_{4} \mathrm{~F}$ crystallizes in the monoclinic space group $P 2_{1} / c ; a=5.6107(5) \AA, b=$ 4.6847(5) $\AA, c=20.2256(18) \AA, \beta=94.145(8)^{\circ}, z=4$. The replacing part of Sb with $Y$ means a slight increase in the unit cell dimensions. The compounds $\mathrm{M}-\mathrm{SbOF}$ and $\alpha-\mathrm{Sb}_{3} \mathrm{O}_{2} \mathrm{~F}_{5}$ have not been grown as single crystals before and it can be concluded that hydrothermal synthesis has proved to be a suitable technique for growing single crystals of antimony oxofluorides because of the relatively low solubility of such compounds compared to other antimony oxohalides that most often have been synthesised at high temperatures by solid state reactions or gas-solid reactions.
\end{abstract}

\section{Introduction}

There are several compounds described in the $\mathrm{Sb}^{3+}-\mathrm{O}-\mathrm{X}(\mathrm{X}=$ $\mathrm{F}, \mathrm{Cl}, \mathrm{Br}, \mathrm{I})$ system e.g. SbOCl, $\mathrm{Sb}_{3} \mathrm{O}_{4} \mathrm{Cl}, \mathrm{Sb}_{8} \mathrm{O}_{11} \mathrm{Cl}_{2}$ and $\mathrm{Sb}_{8} \mathrm{O}_{11} \mathrm{Br}_{2}, \alpha$ - and $\beta-\mathrm{Sb}_{3} \mathrm{O}_{4} \mathrm{I} .{ }^{1-4}$ Five different oxofluorides have previously been reported, three of them are different forms of SbOF denoted as L-SbOF, M-SbOF and $\mathrm{H}$-SbOF and the remaining two are $\alpha-\mathrm{Sb}_{3} \mathrm{O}_{2} \mathrm{~F}_{5}$ and $\beta-\mathrm{Sb}_{3} \mathrm{O}_{2} \mathrm{~F}_{5}{ }^{5,6}$ The hardness/ softness properties of the halide ions are reflected in how they are bonded in the different crystal structures. Fluoride ions form covalent bonds like oxygen to antimony and are integrated in the $\mathrm{Sb}-\mathrm{O}-\mathrm{F}$ framework while the other halide ions act more as counter ions and the structures become separated into oxide parts and halide parts.

The one-sided coordination around p-block cations having stereochemically active lone-pairs increases the chances to find compounds crystallizing in non-centrosymmetric space groups that thus can show non-linear optical properties, e.g. $\mathrm{Te}_{2} \mathrm{SeO}_{7}, \mathrm{Na}_{2} \mathrm{TeW}_{2} \mathrm{O}_{9}$ and $\mathrm{Bi}_{2} \mathrm{TeO}_{5} \cdot{ }^{7-9}$ Oxohalide glasses can also have non-linear optical properties. ${ }^{10}$ Further the lonepairs open up crystal structures and when combining with transition metals it is very often so that the latter arrange in low dimensional arrangements especially in oxohalides like $\mathrm{Cu}_{2} \mathrm{Te}_{2} \mathrm{O}_{5} \mathrm{Cl}_{2}$ and $\mathrm{CuNi}_{5}\left(\mathrm{TeO}_{3}\right)_{4} \mathrm{Cl}_{2}$ where the metal cations tend to bond to both oxygen and halide ions while the lone-

Department of Materials and Environmental Chemistry, Stockholm University, SE-10691 Stockholm, Sweden. E-mail: mats.johnsson@mmk.su.se;

Fax: +46-8-152187; Tel: +46-8-162169

$\dagger$ Electronic supplementary information (ESI) available. See DOI: 10.1039/c6dt01897a pair element tends to bond only to oxygen. ${ }^{11,12}$ Several such compounds show e.g. magnetic frustration.

We have utilized hydrothermal reaction techniques to grow single crystals of oxofluoride compounds and to form monophasic synthesis products. The new compound $\mathrm{Sb}_{3} \mathrm{O}_{4} \mathrm{~F}$ has been synthesized starting with $\mathrm{Sb}_{2} \mathrm{O}_{3}$ and $\mathrm{SbF}_{3}$. The compound $\mathrm{Y}_{0.5} \mathrm{Sb}_{2.5} \mathrm{O}_{4} \mathrm{~F}$ was obtained by introducing $\mathrm{YF}_{3}$ in the reaction mixture. Two previously known compounds $\mathrm{M}$-SbOF and $\alpha-\mathrm{Sb}_{3} \mathrm{O}_{2} \mathrm{~F}_{5}$ were synthesized for the first time as single crystals; the synthesis products were found to be phase pure. The synthesis technique has proved to be suitable for synthesizing oxofluorides, however less suitable for oxohalides comprising $\mathrm{Cl}, \mathrm{Br}$, or I due to the higher solubility product of such compounds.

\section{Experimental}

Single crystals of $\mathrm{Sb}_{3} \mathrm{O}_{4} \mathrm{~F}, \mathrm{Y}_{0.5} \mathrm{Sb}_{2.5} \mathrm{O}_{4} \mathrm{~F}, \mathrm{M}$-SbOF and $\alpha-\mathrm{Sb}_{3} \mathrm{O}_{2} \mathrm{~F}_{5}$ were synthesized by a hydrothermal technique. The compounds were found during investigations of the $\mathrm{Sb}-\mathrm{O}-\mathrm{F}$ and $\mathrm{Y}-\mathrm{Sb}-\mathrm{O}-\mathrm{F}$ systems. All compounds were found from experiments using autoclaves equipped with $18 \mathrm{~mL}$ Teflon liners heated to $230{ }^{\circ} \mathrm{C}$ at a rate of $1.6^{\circ} \mathrm{C} \mathrm{min}^{-1}$. The plateau temperature was maintained for four days and thereafter the temperature was lowered to $30^{\circ} \mathrm{C}$ with the same rate as the heating. As starting materials the following chemicals were used: $\mathrm{Sb}_{2} \mathrm{O}_{3}$ (99.97\%, Sigma-Aldrich), $\mathrm{SbF}_{3}$ (99.8\%, Sigma-Aldrich) and $\mathrm{YF}_{3}$ (99.97\%, Sigma-Aldrich).

$\mathrm{Sb}_{3} \mathrm{O}_{4} \mathrm{~F}$ crystals were obtained from a stoichiometric mixture of $\mathrm{Sb}_{2} \mathrm{O}_{3}: \mathrm{SbF}_{3}=4: 1$ in $1 \mathrm{~mL}$ deionized water. The starting amount was $1.00 \mathrm{mmol} \mathrm{Sb}_{2} \mathrm{O}_{3}$. The experiment yielded 
phase pure colourless $\mathrm{Sb}_{3} \mathrm{O}_{4} \mathrm{~F}$ crystals. Crystals of $\mathrm{Y}_{0.5} \mathrm{Sb}_{2.5} \mathrm{O}_{4} \mathrm{~F}$ and $\mathrm{M}$-SbOF were found from a mixture of $\mathrm{Sb}_{2} \mathrm{O}_{3}: \mathrm{YF}_{3}=3: 1$ in $1 \mathrm{~mL}$ deionized water and some few droplets of HF. The synthesis product was a mixture of yellowish crystals $\left(\mathrm{Y}_{0.5} \mathrm{Sb}_{2.5} \mathrm{O}_{4} \mathrm{~F}\right)$ and transparent colourless crystals (M-SbOF). Phase pure $\mathrm{M}$-SbOF was synthesized from a stoichiometric mixture of $\mathrm{Sb}_{2} \mathrm{O}_{3}: \mathrm{SbF}_{3}=1: 1$ in $1 \mathrm{~mL}$ deionized water, and $\alpha-\mathrm{Sb}_{3} \mathrm{O}_{2} \mathrm{~F}_{5}$ was obtained from an experiment starting with the same molar ratio $\mathrm{Sb}_{2} \mathrm{O}_{3}: \mathrm{SbF}_{3}=1: 1$, however in $1 \mathrm{~mL}$ deionized water plus some few droplets of HF. The weight in amounts is given in the ESI. $\dagger$

Chemical compositions were obtained by EDS using a Hitachi M3000 Table top scanning electron microscope and a JEOL JSB-7000F. The EDS results for $\mathrm{Y}_{0.5} \mathrm{Sb}_{2.5} \mathrm{O}_{4} \mathrm{~F}$ are shown in the ESI. $\dagger$

Single crystal X-ray data were collected using a Bruker D8 Venture diffractometer equipped with a PHOTON 100 detector. Data integration, including the application of a correction for oblique incidence, was performed with the software package SAINT. ${ }^{13}$ Absorption correction was applied by the computer program SADABS. ${ }^{14}$ The crystal structures were solved using the program Superflip and refined by using the program JANA2006. ${ }^{15,16}$ All atoms are refined with anisotropic temperature displacement parameters. Crystallographic data for all compounds are shown in Table 1.

Further details on the crystal structural investigations may be obtained from the Fachinformationszentrum Karlsruhe, 76344 Eggenstein-Leopoldshafen, Germany (Fax: +49-7247-808666; e-mail: crysdata@fiz-karlsruhe.de), on quoting the deposit numbers CSD-431207 for $\mathrm{Sb}_{3} \mathrm{O}_{4} \mathrm{~F}$, CSD-431208 for
$\mathrm{Y}_{0.5} \mathrm{Sb}_{2.5} \mathrm{O}_{4} \mathrm{~F}$, CSD-431209 for M-SbOF, and CSD-431210 for $\alpha-\mathrm{Sb}_{3} \mathrm{O}_{2} \mathrm{~F}_{5}$.

Powder X-ray data were collected on a Panalytical X'Pert PRO powder X-ray diffractometer in Bragg-Brentano geometry with $\mathrm{Cu}-\mathrm{K} \alpha$ radiation. Rietveld refinement and the comparison of powder patterns against single crystal data were made by using the program Jana2006.

Thermogravimetric analyses (TG) were performed using a TA instruments Discovery equipment. The measurements were carried out in air with a heating rate of $5{ }^{\circ} \mathrm{C} \min ^{-1}$ up to $700{ }^{\circ} \mathrm{C}$, starting with an $\sim 0.5 \mathrm{mg}$ sample.

\section{Results and discussion}

It was found to be possible to synthesize the compounds $\mathrm{Sb}_{3} \mathrm{O}_{4} \mathrm{~F}, \mathrm{Y}_{0.5} \mathrm{Sb}_{2.5} \mathrm{O}_{4} \mathrm{~F}, \alpha-\mathrm{Sb}_{3} \mathrm{O}_{2} \mathrm{~F}_{5}$, and $\mathrm{M}$-SbOF by hydrothermal synthesis. The two isostructural compounds $\mathrm{Sb}_{3} \mathrm{O}_{4} \mathrm{~F}$ and $\mathrm{Y}_{0.5} \mathrm{Sb}_{2.5} \mathrm{O}_{4} \mathrm{~F}$ are new while $\alpha-\mathrm{Sb}_{3} \mathrm{O}_{2} \mathrm{~F}_{5}$ and $\mathrm{M}$-SbOF are known for a long time. $\alpha-\mathrm{Sb}_{3} \mathrm{O}_{2} \mathrm{~F}_{5}$ in the form of powder has previously been synthesised by reacting $\mathrm{SbF}_{3}$ and $\mathrm{NH}_{4} \mathrm{~F}$ in water at room temperature and $\mathrm{M}-\mathrm{SbOF}$ has previously been synthesized as powder by solid state reactions in gold tubes at $220-260{ }^{\circ} \mathrm{C} .6,17$

\section{The crystal structure of $\mathrm{Sb}_{3} \mathrm{O}_{4} \mathrm{~F}$ and $\mathrm{Y}_{0.5} \mathrm{Sb}_{2.5} \mathrm{O}_{4} \mathrm{~F}$}

The $\mathrm{Sb}_{3} \mathrm{O}_{4} \mathrm{~F}$ crystal structure consists of three crystallographically independent $\mathrm{Sb}$ atoms having $\left[\mathrm{Sb}(1) \mathrm{O}_{3}\right],\left[\mathrm{Sb}(2) \mathrm{O}_{3} \mathrm{~F}\right]$ and $\left[\mathrm{Sb}(3) \mathrm{O}_{3}\right]$ trigonal pyramidal and see-saw co-ordinations, see Fig. 1. If bond distances on the wedge to be included in the

Table 1 Crystallographic data for the four compounds investigated

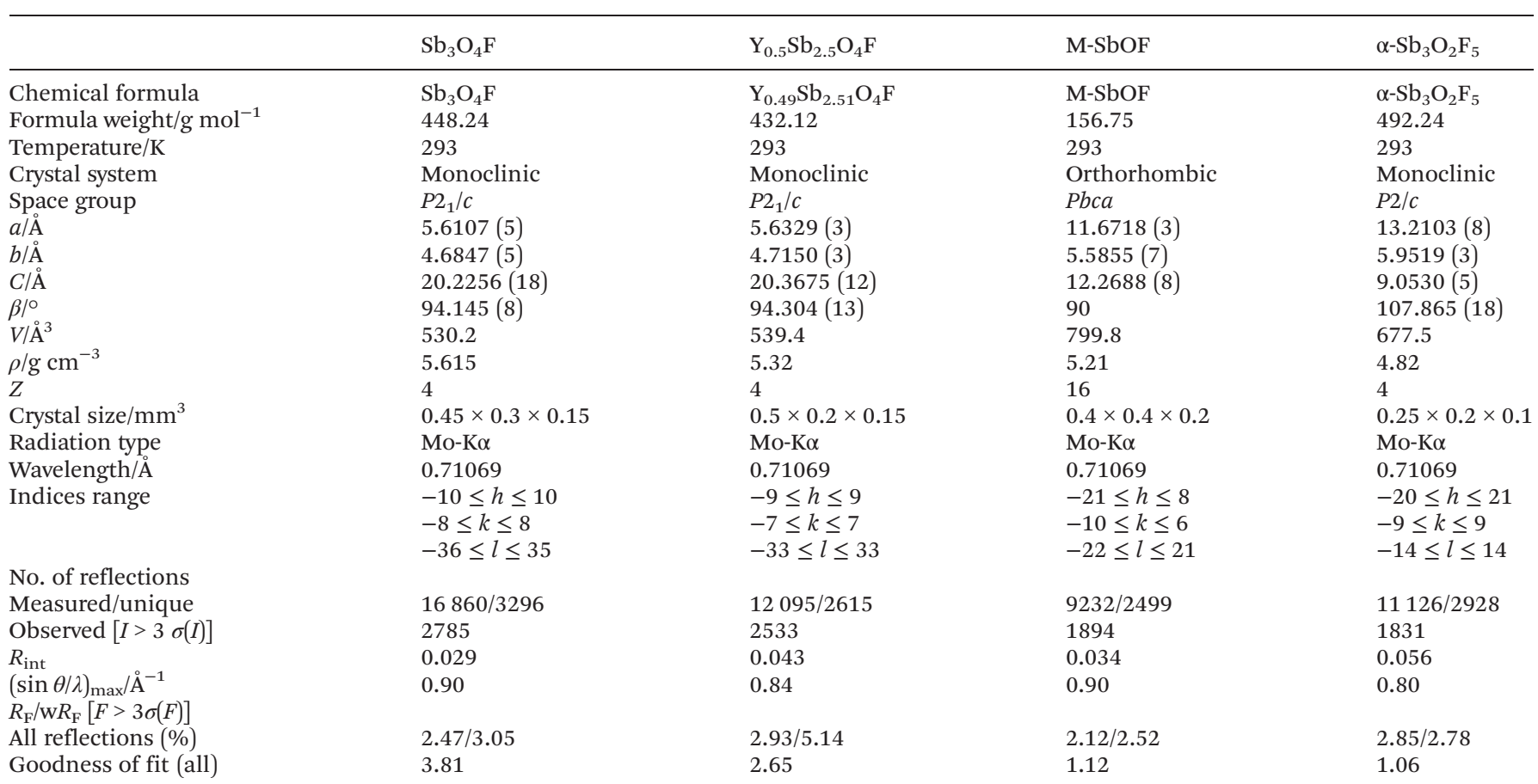






Fig. 1 The asymmetric unit and selected equivalents of $\mathrm{Sb}_{3} \mathrm{O}_{4} \mathrm{~F}$. There are three crystallographic independent $\mathrm{Sb}$ atoms having $\left[\mathrm{Sb}(1) \mathrm{O}_{3}\right]$, $\left[\mathrm{Sb}(2) \mathrm{O}_{3} \mathrm{~F}\right]$ and $\left[\mathrm{Sb}(3) \mathrm{O}_{3}\right]$ trigonal pyramidal and see-saw co-ordinations. Symmetry codes: (i) $-1+x, y, z$; (ii) $-x,-y,-z$; (iii) $-x,-0.5+y, 0.5-z$. primary coordination sphere are also included we end up with $\left[\mathrm{Sb}(1) \mathrm{O}_{3+1} \mathrm{~F}\right],\left[\mathrm{Sb}(2) \mathrm{O}_{3+1} \mathrm{~F}\right]$ and $\left[\mathrm{Sb}(3) \mathrm{O}_{3}\right]$ co-ordinations. The long $\mathrm{Sb}(1)-\mathrm{O}(2)$ and $\mathrm{Sb}(2)-\mathrm{O}(4)$ bond distances are 2.586(2) $\AA$ and 2.679(2) $\AA$ respectively and the long $\mathrm{Sb}(1)-\mathrm{F}$ distance is 2.630(2) $\AA$. The operative definition of the outer primary coordination sphere according to Brown suggests this to be $2.76 \AA$ for $\mathrm{Sb}-\mathrm{O}$ and $2.67 \AA$ for $\mathrm{Sb}-\mathrm{F}^{18}{ }^{18}$ The $\mathrm{Sb}-\mathrm{O}$ bond distances of $\sim 2.0 \AA$ in the $\left[\mathrm{SbO}_{3}\right]$ building blocks show very close proximity to the $\mathrm{Sb}-\mathrm{O}$ distances in cubic $\mathrm{Sb}_{2} \mathrm{O}_{3}$, however the $\mathrm{Sb}-\mathrm{O}-\mathrm{Sb}$ angles differ slightly. ${ }^{19}$

The pairs of edge sharing $\left[\mathrm{Sb}(2) \mathrm{O}_{3} \mathrm{~F}\right]$ polyhedra are further bridged by two corner sharing $\left[\mathrm{Sb}(1) \mathrm{O}_{3}\right]$ units to make $\left[\mathrm{Sb}_{2} \mathrm{O}_{3} \mathrm{~F}\right]_{n}$ chains extending along [100], see Fig. 2a. The $\left[\mathrm{Sb}(3) \mathrm{O}_{3}\right]$ trigonal pyramids are corner sharing and make up $\left[\mathrm{Sb}(3) \mathrm{O}_{2}\right]_{n}$ chains extending along [010], see Fig. $2 \mathrm{~b}$. The two chain systems connect via $\mathrm{Sb}(1)-\mathrm{O}(4)-\mathrm{Sb}(3)-\mathrm{O}(3)-\mathrm{Sb}(3)-\mathrm{O}(4)-$ $\mathrm{Sb}(1)$ to make up the three dimensional framework of $\mathrm{Sb}_{3} \mathrm{O}_{4} \mathrm{~F}$ where the $\mathrm{F}$ atoms protrude into cavities in the structure and are thus not participating in building the framework, see

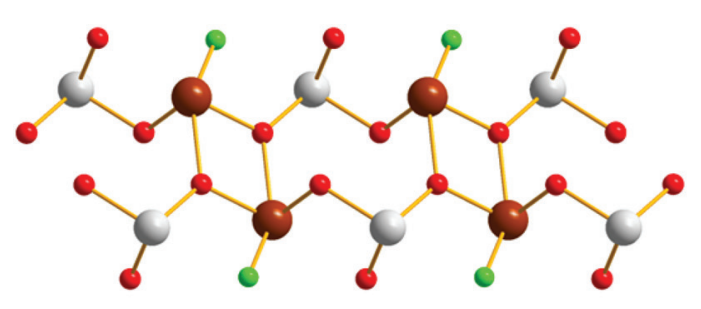

a

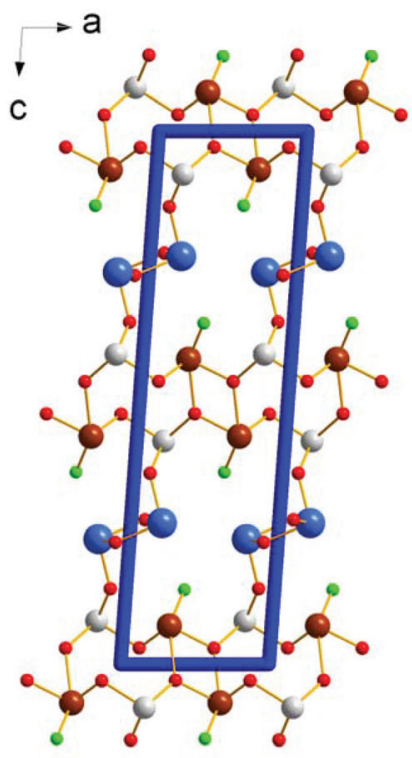

c

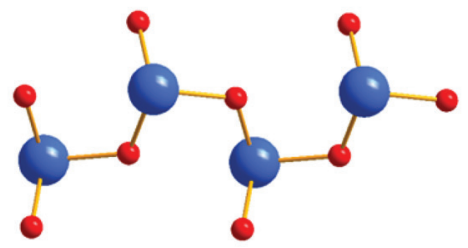

b



d

Fig. 2 (a) Pairs of edge sharing $\left[\mathrm{Sb}(2) \mathrm{O}_{3} \mathrm{~F}\right]$ polyhedra are bridged by corner sharing $\mathrm{Sb}(1) \mathrm{O}_{3}$ units to make $\left[\mathrm{Sb}_{2} \mathrm{O}_{3} \mathrm{~F}\right]_{n}$ chains extending along $[100]$. (b) The $\left[\mathrm{Sb}(3) \mathrm{O}_{3}\right]$ trigonal pyramids make up $\left[\mathrm{Sb}(3) \mathrm{O}_{2}\right]_{n}$ chains by corner sharing that extend along [010]. (c and d) The two chain systems connect and form the three dimensional network of $\mathrm{Sb}_{3} \mathrm{O}_{4} \mathrm{~F}$ where the $\mathrm{F}$ atoms protrude into cavities in the structure. Grey atoms indicate $\mathrm{Sb}(1)$, brown $\mathrm{Sb}(2)$, blue $\mathrm{Sb}(3)$, and red $\mathrm{O}$ and green stands for $\mathrm{F}$. 
Fig. 2c and d. The allocation of $\mathrm{O}$ and $\mathrm{F}$ was based on BVS calculations that show slight hyper-valence for $\mathrm{Sb}$ and $\mathrm{O}$ and hypo-valence for $\mathrm{F}$ indicating its more ionic nature (ESI $\dagger$ ). It is not uncommon in oxohalides that halide ions show hypovalence. $^{20,21}$ The lone electron pairs, E, on the three crystallographically different $\mathrm{Sb}^{3+}$ ions are stereochemically active and occupy space in the crystal structure and thus become responsible for the open framework that can be seen in Fig. 2c and d. For $\mathrm{Sb}(1)$ and $\mathrm{Sb}(3)$ the lone-pairs take apex positions in $\left[\mathrm{SbO}_{3} \mathrm{E}\right]$ tetrahedra, and for $\mathrm{Sb}(2)$ it forms a $\left[\mathrm{SbO}_{3} \mathrm{FE}\right]$ trigonal bipyramid where $\mathrm{E}$ sits at one of the corners of the base plane of the pyramid. The lone-pairs on $\mathrm{Sb}^{3+}$ point into the voids (channels) of the crystal structure as the F-atoms.

A phase pure sample of $\mathrm{Sb}_{3} \mathrm{O}_{4} \mathrm{~F}$ could be obtained from a stoichiometric ratio of the starting materials, see Fig. 3.

$\mathrm{Y}_{0.5} \mathrm{Sb}_{2.5} \mathrm{O}_{4} \mathrm{~F}$ is isostructural to $\mathrm{Sb}_{3} \mathrm{O}_{4} \mathrm{~F}$ and the presence of $\mathrm{Y}$ is responsible for the yellow colour as $\mathrm{Sb}_{3} \mathrm{O}_{4} \mathrm{~F}$ is colourless. $\mathrm{Y}$ partly occupies all three $\mathrm{Sb}$ positions in the crystal structure. The insertion of $\mathrm{Y}$ is responsible for the $0.14 \AA$ elongation of the $c$-axis and while the $a$ - and $b$-axes are not significantly influenced. All $\mathrm{Sb}-\mathrm{O}$ and $\mathrm{Sb}-\mathrm{F}$ distances are slightly longer in $\mathrm{Y}_{0.5} \mathrm{Sb}_{2.5} \mathrm{O}_{4} \mathrm{~F}$ compared to those in $\mathrm{Sb}_{3} \mathrm{O}_{4} \mathrm{~F}$, see the ESI. $\uparrow$ When synthesizing $\mathrm{Y}_{0.5} \mathrm{Sb}_{2.5} \mathrm{O}_{4} \mathrm{~F}$ the addition level of $\mathrm{HF}$ turned out to be very important in order to incorporate $\mathrm{Y}$ into the structure. Synthesis attempts were made with increased water content but it did not yield $\mathrm{Y}$ incorporated in $\mathrm{Sb}^{3+}-\mathrm{O}-\mathrm{F}$ compounds.

\section{$\mathrm{M}-\mathrm{SbOF}$ and $\alpha-\mathrm{Sb}_{3} \mathrm{O}_{2} \mathrm{~F}_{5}$}

The compounds $\alpha-\mathrm{Sb}_{3} \mathrm{O}_{2} \mathrm{~F}_{5}$ and $\mathrm{M}$-SbOF were found while attempting to synthesize $\mathrm{Y}_{0.5} \mathrm{Sb}_{2.5} \mathrm{O}_{4} \mathrm{~F}$. It was also possible to synthesize both phase pure $\alpha-\mathrm{Sb}_{3} \mathrm{O}_{2} \mathrm{~F}_{5}$ and $\mathrm{M}-\mathrm{SbOF}$ from a mixture of $\mathrm{SbF}_{3}$ and $\mathrm{Sb}_{2} \mathrm{O}_{3}, c f$. the Experimental section. The structure determination resulted in the same model as has previously been reported. ${ }^{6,17}$ However, the present data also allowed refining the ADPs, see Fig. 4a. The present model has a slightly smaller unit cell and small changes in bond distances compared to the older model. Bond-valence sum (BVS) calculations support that the valences are $\mathrm{Sb}^{3+}, \mathrm{O}^{2-}$ and $\mathrm{F}^{-}$ with slightly over-bonded antimony cations and oxygen anions and under-bonded fluorine atoms (see the ESI $\dagger$ ). ${ }^{22}$ The compound M-SbOF has been described by Åström. ${ }^{17}$ The present structure determination also allows for anisotropic ADPs, see Fig. $4 \mathrm{~b}$.

\section{Thermal gravimetry}

The thermal decomposition of the compounds $\mathrm{Sb}_{3} \mathrm{O}_{4} \mathrm{~F}$, $\mathrm{M}-\mathrm{SbOF}$ and $\alpha-\mathrm{Sb}_{3} \mathrm{O}_{2} \mathrm{~F}_{5}$ is shown in Fig. 5. Based on the weight changes the new compound $\mathrm{Sb}_{3} \mathrm{O}_{4} \mathrm{~F}$ decomposes in two steps to first give off $\mathrm{SbF}_{3}\left(340-380{ }^{\circ} \mathrm{C}\right)$ and subsequently SbOF in the second step (450-550 ${ }^{\circ} \mathrm{C}$ ), see reactions (1) and (2) below. Finally at $550-600{ }^{\circ} \mathrm{C}$ there is a slight weight increase when $\mathrm{Sb}_{2} \mathrm{O}_{3}$ partly oxidizes to $\mathrm{Sb}_{2} \mathrm{O}_{5}$, the latter step is in accordance with previous observations. ${ }^{23}$

$$
\begin{gathered}
4 \mathrm{Sb}_{3} \mathrm{O}_{4} \mathrm{~F}(\mathrm{~s}) \rightarrow 5 \mathrm{Sb}_{2} \mathrm{O}_{3}(\mathrm{~s})+\mathrm{L}-\mathrm{SbOF}(\mathrm{s})+\mathrm{SbF}_{3}(\mathrm{~g}) \\
5 \mathrm{Sb}_{2} \mathrm{O}_{3}(\mathrm{~s})+\mathrm{L}-\mathrm{SbOF}(\mathrm{s}) \rightarrow 5 \mathrm{Sb}_{2} \mathrm{O}_{3}(\mathrm{~s})+\mathrm{L}-\mathrm{SbOF}(\mathrm{g}) \\
\mathrm{Sb}_{2} \mathrm{O}_{3}(\mathrm{~s})+\mathrm{O}_{2}(\mathrm{~g}) \rightarrow \mathrm{Sb}_{2} \mathrm{O}_{5}(\mathrm{~s})
\end{gathered}
$$

The compound M-SbOF decomposes $\left(250-500{ }^{\circ} \mathrm{C}\right.$ ) in one step (4) with subsequent oxidation according to step (3).

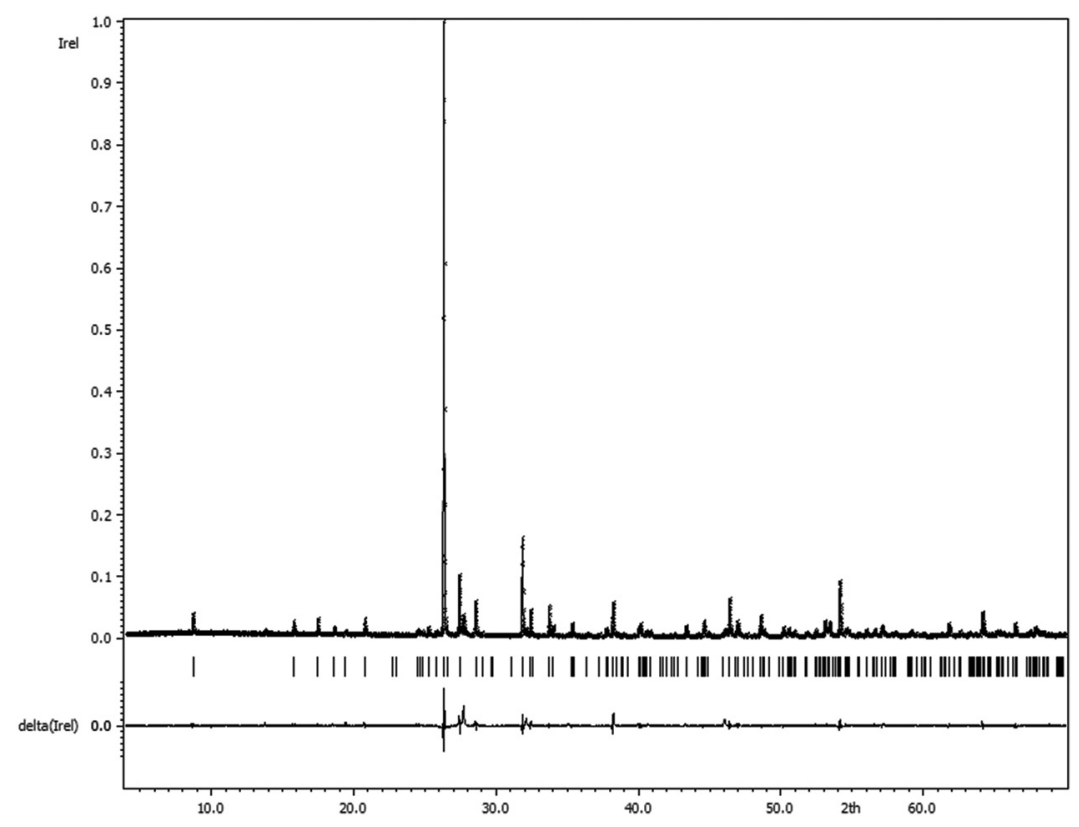

Fig. 3 Comparison of the measured powder $\mathrm{X}$-ray diffractogram and the calculated pattern for $\mathrm{Sb}_{3} \mathrm{O}_{4} \mathrm{~F}$ based on the single crystal $\mathrm{X}$-ray determination of the crystal structure $\left(R_{\mathrm{p}}=9.43\right)$. 


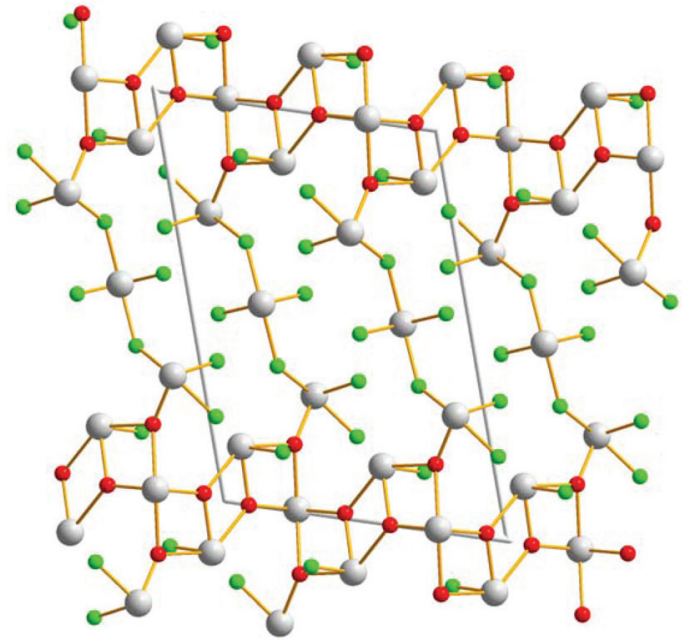

a

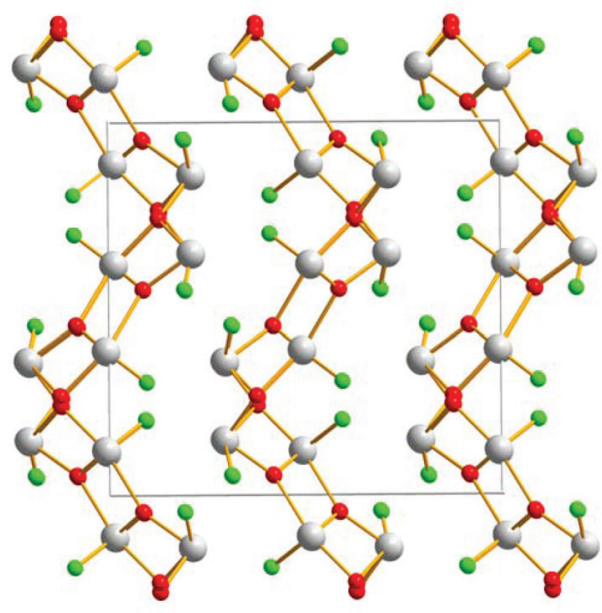

b

Fig. 4 Crystal structures of (a) $\alpha-\mathrm{Sb}_{3} \mathrm{O}_{2} \mathrm{~F}_{5}$ and (b) M-SbOF, projected along [010]. Grey atoms indicate Sb, red stands for O, and green stands for $\mathrm{F}$.

$$
3 \mathrm{M}-\mathrm{SbOF}(\mathrm{s}) \rightarrow \mathrm{Sb}_{2} \mathrm{O}_{3}(\mathrm{~s})+\mathrm{SbF}_{3}(\mathrm{~g})
$$

The compound $\alpha-\mathrm{Sb}_{3} \mathrm{O}_{2} \mathrm{~F}_{5}$ also decomposes $\left(225-325{ }^{\circ} \mathrm{C}\right)$ in one step (5) with subsequent oxidation according to step (3).

$$
3 \alpha-\mathrm{Sb}_{3} \mathrm{O}_{2} \mathrm{~F}_{5}(\mathrm{~s}) \rightarrow 2 \mathrm{Sb}_{2} \mathrm{O}_{3}(\mathrm{~s})+5 \mathrm{SbF}_{3}(\mathrm{~g})
$$

It can be concluded that $\mathrm{Sb}_{3} \mathrm{O}_{4} \mathrm{~F}$ is thermally more stable than M-SbOF and $\alpha-\mathrm{Sb}_{3} \mathrm{O}_{2} \mathrm{~F}_{5}$.
(4) Comparison with other $\mathrm{Sb}-\mathrm{O}-\mathrm{X}$ compounds

Most compounds in the system $\mathrm{Sb}^{3+}-\mathrm{O}-\mathrm{X}(\mathrm{X}=\mathrm{F}, \mathrm{Cl}, \mathrm{Br}, \mathrm{I})$ are layered e.g. $\mathrm{Sb}_{4} \mathrm{O}_{5}\left(\mathrm{Cl}, \mathrm{Br}_{2}\right),{ }^{24,25} \mathrm{Sb}_{5} \mathrm{O}_{7} \mathrm{I},{ }^{26} \mathrm{Sb}_{8} \mathrm{O}_{11}(\mathrm{Cl}, \mathrm{Br}, \mathrm{I})_{2}{ }^{3,20}$ $\mathrm{Sb}_{3} \mathrm{O}_{4} \mathrm{I},{ }^{2} \mathrm{SbOCl},{ }^{1}$ and $\mathrm{M}-\mathrm{SbOF} .{ }^{17}$ Exceptions are $\mathrm{Sb}_{3} \mathrm{O}_{4} \mathrm{I}^{4}$ that show ladders of $\left[\mathrm{Sb}_{3} \mathrm{O}_{4}\right]_{n}$ with I-atoms in between, the compounds $\alpha-\mathrm{Sb}_{3} \mathrm{O}_{2} \mathrm{~F}_{5}, \mathrm{~L}-\mathrm{SbOF}^{5}$ and the present compound $\mathrm{Sb}_{3} \mathrm{O}_{4} \mathrm{~F}$ that are 3D-frameworks. The compounds in the system $\mathrm{Sb}^{3+}-\mathrm{O}-\mathrm{F}$ have direct covalent bonds in between $\mathrm{Sb}^{3+}$ and $\mathrm{F}$ while when the halide ion is one of $\mathrm{Cl}, \mathrm{Br}$ or I there is a separation into an oxide part consisting of a $\mathrm{Sb}-\mathrm{O}$ framework made

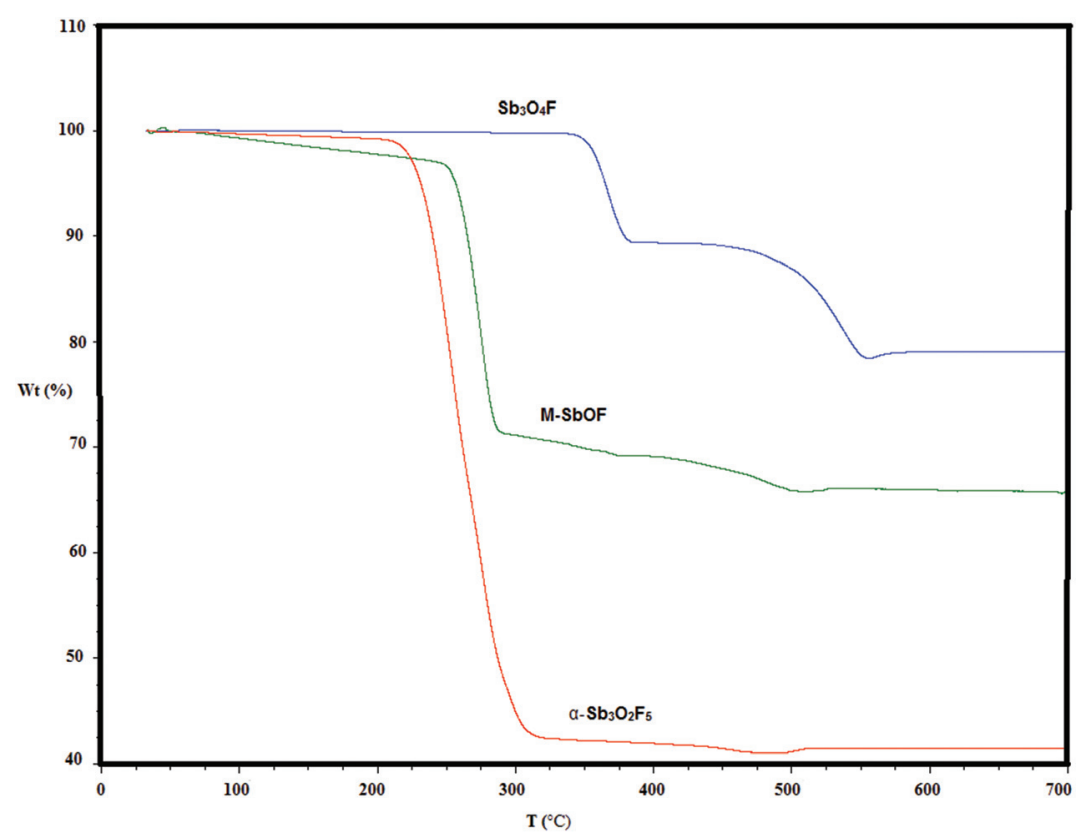

Fig. 5 Thermal decomposition of the compounds $\mathrm{Sb}_{3} \mathrm{O}_{4} \mathrm{~F}, \mathrm{M}-\mathrm{SbOF}$ and $\alpha-\mathrm{Sb}_{3} \mathrm{O}_{2} \mathrm{~F}_{5}$, see the text for interpretation of the decomposition steps. 


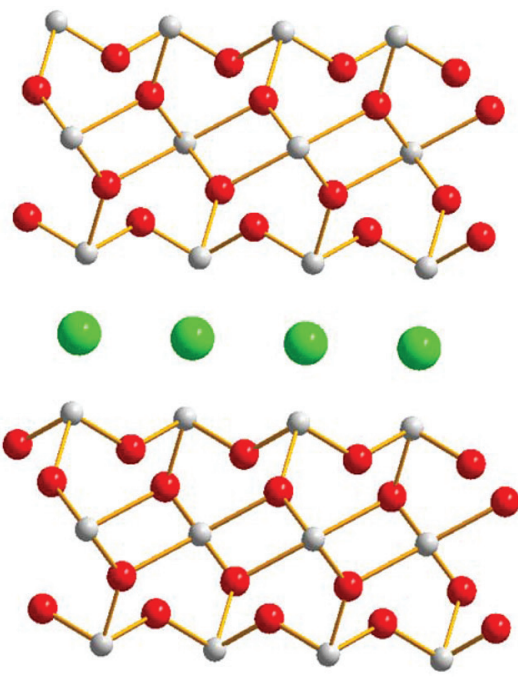

a
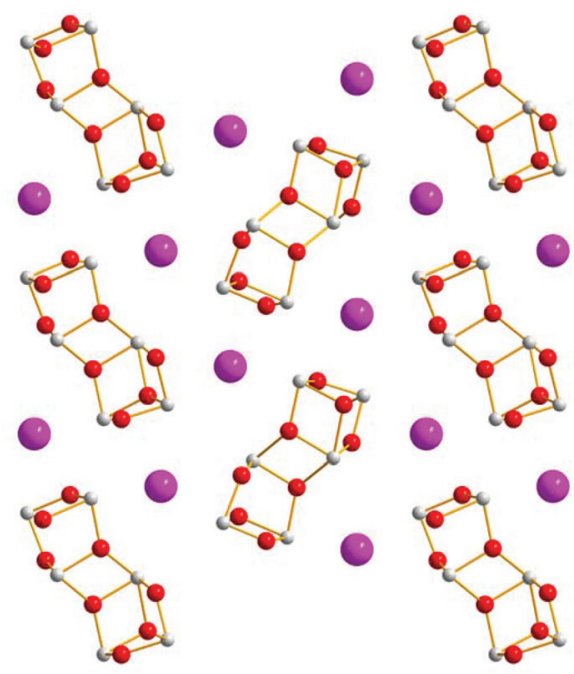

b

Fig. 6 (a) $\mathrm{Sb}_{3} \mathrm{O}_{4} \mathrm{Cl}$ consists of $\left[\mathrm{Sb}_{3} \mathrm{O}_{4}\right]_{n}$ layers parallel to [100] with $\mathrm{Cl}$ atoms situated in between the layers. (b) The compound $\alpha-\mathrm{Sb}_{3} \mathrm{O}_{4} \mathrm{l}$ is composed of $\left[\mathrm{Sb}_{3} \mathrm{O}_{4}\right]_{n}$ tubes along $[100]$ separated by I atoms.

up of $\left[\mathrm{SbO}_{3}\right]$ and $\left[\mathrm{SbO}_{4}\right]$ building blocks and a halide part where those ions take the role of counter ions in the crystal structures. However, there is one exception, SbOCl, where there is covalent $\mathrm{Sb}^{3+}-\mathrm{Cl}$ bonds and trigonal pyramidal $\left[\mathrm{SbO}_{2} \mathrm{Cl}\right]$ building blocks.

The oxohalides with the common formula $\mathrm{Sb}_{3} \mathrm{O}_{4} \mathrm{X}(\mathrm{X}=\mathrm{Cl}$, I) have completely different crystal structures compared to the present compound $\mathrm{Sb}_{3} \mathrm{O}_{4} \mathrm{~F}$. $\mathrm{Sb}_{3} \mathrm{O}_{4} \mathrm{Cl}$ has a monoclinic structure that crystallizes in the space group $P 2 / c^{27}$ It consists of $\left[\mathrm{Sb}_{3} \mathrm{O}_{4}\right]_{n}$ layers parallel to (100) with $\mathrm{Cl}$ atoms situated in between the layers, see Fig. 6a. BVS calculations show the ionic character of the $\mathrm{Cl}$ atoms $\left(V_{\mathrm{i}}=0.64\right) . \mathrm{Sb}_{3} \mathrm{O}_{4} \mathrm{I}$ exists in two similar forms; orthorhombic $\alpha$-phase (space group $P b n 2_{1}$ ) and monoclinic $\beta$-phase (space group $P 2_{1} / c$ ). The structures are composed of $\left[\mathrm{Sb}_{3} \mathrm{O}_{4}\right]$ infinite $\mathrm{Sb}-\mathrm{O}$ tubes along [100] that are separated by I atoms. ${ }^{4}$ The $\alpha$-phase is shown in Fig. $6 \mathrm{~b}$. BVS calculation on I $\left(V_{\mathrm{i}}=0.80\right)$ reveals a more covalent character for I than for $\mathrm{Cl}$. The main difference between $\mathrm{Sb}_{3} \mathrm{O}_{4} \mathrm{~F}$ and the $\mathrm{Cl}$ - and I analogues is that $\mathrm{F}$ is incorporated in the $\mathrm{Sb}-\mathrm{O}-\mathrm{F}$ network while for the other two the oxide part and the halide part of the crystal structures are separated.

\section{Conclusions}

The single crystals of $\mathrm{Sb}_{3} \mathrm{O}_{4} \mathrm{~F}, \mathrm{Y}_{0.5} \mathrm{Sb}_{2.5} \mathrm{O}_{4} \mathrm{~F}$ and the two previously known Sb-O-F compounds, $3 \mathrm{M}-\mathrm{SbOF}$ and $\alpha-\mathrm{Sb}_{3} \mathrm{O}_{2} \mathrm{~F}_{5}$, were successfully synthesized by hydrothermal methods at $230{ }^{\circ} \mathrm{C}$. Depending on subtle differences in the synthesis method the different compounds were obtained. An interesting outcome of the work is the incorporation of yttrium in $\mathrm{Sb}_{3} \mathrm{O}_{4} \mathrm{~F}$ to form $\mathrm{Y}_{0.5} \mathrm{Sb}_{2.5} \mathrm{O}_{4} \mathrm{~F}$ at such a low temperature used.
The new compound $\mathrm{Sb}_{3} \mathrm{O}_{4} \mathrm{~F}$ is built from $\mathrm{SbO}_{3}$ and $\mathrm{SbO}_{3} \mathrm{~F}$ polyhedra to form a three dimensional network. Incorporation of yttrium to form $\mathrm{Y}_{0.5} \mathrm{Sb}_{2.5} \mathrm{O}_{4} \mathrm{~F}$ causes an elongation of the unit cell parameters. The three crystallographically different $\mathrm{Sb}$ sites in the crystal structure are all partially occupied by $\mathrm{Y}$. The compounds $\mathrm{M}$-SbOF and $\alpha-\mathrm{Sb}_{3} \mathrm{O}_{2} \mathrm{~F}_{5}$ were previously synthesized by solid state reactions and in this work it was shown that they can form also by hydrothermal reactions. Accurate crystal structures of both compounds were determined from the single-crystal X-ray diffraction data. With respect to the previous structure refinement against powder X-ray diffraction the principal difference is the present refinement of anisotropic ADPs in the present study.

\section{Acknowledgements}

Financial support from Stiftelsen Olle Engkvist Byggmästare and the Swedish Research Council is acknowledged.

\section{References}

1 M. Edstrand, Ark. Kemi, 1953, 6, 89-112.

2 H. Katze, Y. Oka, Y. Kanke and T. Z. Yao, Z. Kristallogr., 1999, 214, 284-289.

3 Z. Mayerova, M. Johnsson and S. Lidin, Solid State Sci., 2006, 8, 849-854.

4 Z. Hugonin, M. Johnsson and S. Lidin, Solid State Sci., 2009, 11, 24-28.

5 A. Åström and S. Andersson, Acta Chem. Scand., 1971, 25, 1519-1520. 
6 A. A. Udovenko, L. A. Zemnukhova, E. V. Kovaleva and G. A. Fedorishcheva, Russ. J. Coord. Chem., 2004, 30, 618-624.

7 Y. Porter, K. M. Ok, N. S. P. Bhuvanesh and P. S. Halasyamani, Chem. Mater., 2001, 13, 1910-1915.

8 J. Goodey, J. Broussard and P. S. Halasyamani, Chem. Mater., 2002, 14, 3174-3180.

9 K. M. Ok, N. S. P. Bhuvanesh and P. S. Halasyamani, Inorg. Chem., 2001, 40, 1978-1980.

10 R. E. de Araujo, C. B. de Araújo, G. Poirier, M. Poulain and Y. Messaddeq, Appl. Phys. Lett., 2002, 25, 4694-4696.

11 M. Johnsson, K. W. Törnroos, F. Mila and P. Millet, Chem. Mater., 2000, 12, 2853-2857.

12 M. Johnsson, K. W. Törnroos, P. Lemmmens and P. Millet, Chem. Mater., 2003, 15, 68-73.

13 Bruker AXS Inc., Madison, Wisconsin, USA, 2012.

14 G. M. Sheldrick, SADABS, Version 2008/1.

15 L. Palatinus and G. Chapuis, J. Appl. Crystallogr., 2007, 40, 785-790.

16 V. Petricek, M. Dusek and L. Palatinus, Z. Kristallogr., 2014, 229, 345-352.
17 A. Åström, Acta Chem. Scand., 1972, 26, 3849-3854.

18 I. D. Brown, Chemical bond in inorganic chemistry, Oxford University Press, New York, 2002.

19 C. Svensson, Acta Crystallogr., Sect. B: Struct. Crystallogr. Cryst. Chem., 1975, 31, 2016-2018.

20 S. Lidin, M. Johnsson and Z. Hugonin, Solid State Sci., 2009, 11, 1198-1205.

21 S. Hu, M. Johnsson, P. Lemmens, D. Schmid, D. Menzel, J. Tapp and A. Möller, Chem. Mater., 2014, 26, 3631-3636.

22 N. E. Brese and M. O'Keeffe, Acta Crystallogr., Sect. B: Struct. Sci., 1991, 47, 192-197.

23 P. Čerič and B. Bukovec, Thermochim. Acta, 1992, 195, 7384.

24 M. Edstrand, Acta Chem. Scand., 1947, 1, 178-203.

25 C. Saernstrand, Acta Crystallogr., Sect. B: Struct. Crystallogr. Cryst. Chem., 1978, 34, 2402-2407.

26 V. Kraemer, Acta Crystallogr., Sect. B: Struct. Crystallogr. Cryst. Chem., 1975, 31, 234-237.

27 T. Katzke, H. Oka, Y. Kanke, Y. Kato and K. Yao, Z. Kristallogr., 1999, 284, 284-289. 